\title{
生葉の熟度による香気寄与成分の変化
}

\author{
国立研究開発法人 \\ 農業・食品産業技術総合研究機構 \\ 果樹茶業研究部門* \\ 水上裕 造 $^{\dagger}$
}

（2019年 3 月 12 日受理）

\section{Changes in Key Odorants in Fresh Tea Leaves with Maturity}

\author{
Yuzo Mizukami \\ NARO Institute of Fruit Tree and Tea Science
}

\begin{abstract}
Summary
Odorants in aroma extracts isolated from fresh tea leaves change as tea leaves grow. Elucidation of these changes with tea leaf maturity is essential for the cultivation, manufacturing, and quality control. Aroma volatiles were extracted from fresh tea leaf samples using the solvent-assisted flavor evaporation technique $\left(10^{-3} \mathrm{~Pa}\right)$. An aroma extract dilution analysis applied to the volatile fractions revealed hexanal, (Z)-3-hexenal, (Z)1,5-octadien-3-one, (Z)-3-hexenol, 2-isopropyl-3-methoxypyrazine and 2-isobutyl-3-methoxypyrazine were detected with high flavor dilution (FD) factors. These 6 compounds increased with tea leaf maturity, as confirmed by the gas chromatography - mass spectrometry. On the other hand, two other odorants, coumarin and vanillin, were detected with low FD factors and decreased with leaf maturity. This result would be a good contribution to the improvement of cultivation and manufacturing technology, as well as quality control of tea.
\end{abstract}

Key words : fresh tea leaves, odorant, maturity, aroma extract dilution analysis.

キーワード : 生葉, 香気寄与成分, 成熟, 香気エキス希釈分析

\section{1 緒 言}

現在, わが国で生産されている煎茶は, 生葉を蒸熱し, 乾燥と揉捻を経て製造される。煎茶の品質は生葉の熟度 によって大きく異なる。一番茶初期に収穫して製造され
たものは若芽の甘い香りや新鮮なみる芽香があり, 高值 で取引されるが, 摘採後期ではこわ葉臭や木茥臭が感じ られ市場価格は低下する ${ }^{1)}$ 。良質な茶を生産するために は摘採時期の判定が重要である。これまで茶芽の熟度と 呈味成分を中心とした品質関連成分の解明が行われてき た $^{2,3)}$ 。香気成分については, 小柳津ら ${ }^{1)} に よ り$ 詳細に 
調べられ，ガスクロマトグラフィー (GC) 分析から生 葉の熟度の進行により $(E, E$ and $Z)-2,4$-heptadienals, (Z)-2-pentn-1-ol, hexanal, (Z)-2-heptenalが増加し, こ わ葉臭への関与が示唆された。一方, linalool oxides, coumarin, 7,8-dihydro-beta-ionone, $(E)$-2-hydroxycinnamic acid, heptanoic acid は生葉の熟度の進行により含有量 が低下することから若芽の持つ甘い香りや新鮮なみる芽 香に寄与している可能性が示唆された。これらの知見は 荒茶から香気成分を抽出して得られたものであるが ${ }^{1)}$, 製茶工程において香気成分が増減し ${ }^{4)}$ ，茶の香りに影響 することが考えられる。そこで本研究では基礎的デー夕 を得ることを目的に, 生葉から直接香気エキスを抽出し, 熟度の進行による成分の変化を明らかにする。

今回, チャの生葉として若芽と熟度が進行したこわ葉 から直接溶媒で香りを抽出し, Solvent-assisted flavor evaporation（SAFE）装置を用いた高真空蒸留により 香気エキスを得て，GC-オルファファクトメトリー $(\mathrm{O})$ を用いて分析した。そして，GC-Oを用いた香気エキス 希釈分析 (Aroma Extract Dilution Analysis, AEDA) により元の香りへの影響度合いを示すFlavor dilution factor（FDファクター）を求めた。GC-Oは人の鼻を検 出器として利用することにより, GCでは検出されにく い低濃度の成分も検出できる。これまでGC-Oを用いて 煎茶，ほうじ茶，烏龍茶および紅茶の香りに寄与する成 分が解明されている ${ }^{5-7)}$ 。さらに, AEDAから熟度の進 行によりFDファクターが増減する成分を抽出し, それ らの成分の熟度による変化を分析した。本研究により得 られた結果はこわ葉臭等の解明や今後の栽培および加工 技術の発展に貢献することが予想される。

\section{2 実験方法}

\section{1 材料}

材料に用いた生葉は2014年 4 月 28 日から 5 月 14 日にお
いて, 農研機構野菜茶業研究所 (現果樹茶業研究部門) 金谷茶業研究拠点試験研究戒場で摘採した品種 ‘やぶき た’を用いた。なお，実験に用いた生葉の摘採日と原葉 形質をTable 1 に示した。原葉形質は既報 ${ }^{8)}$ に従い求め た。なお葉割合は葉と茎の含水率を 2 回繰り返して求め (電子レンジで乾燥, $600 \mathrm{w}, 12$ 分), 乾物重から葉の割 合を算出した。

香気成分の抽出, シリカゲルを用いたカラムクロマ トグラフィーおよび成分の合成に用いた溶媒は既報 9,10$)$ と同様にシュナイダー管で精製した。Table 2に示した 成分No. 1，5-7，9-11，13，16-22，25，26，28，30，31， 34-37は東京化成工業 (東京) から, No.23, 29はシグマア ルドリッチジャパン (東京)から入手した。成分No. 3, 8, 12 は既報 ${ }^{11)}$ と同様に $N$-tert-butylphenylsulfenamide（東 京化成工業）を触媒， $N$-chlorosuccinimide（東京化成 工業）を共酸化剤として，それぞれ基質となるalcoholか ら合成した。No.15 ${ }^{12)} ， 27^{13)}$ は既報の方法を参考に得たが， 一級アルコールの酸化はMukaiyamaら ${ }^{11)}$ の方法を用い て行った。各成分の保持指標を求めるため, paraffine $\left(\mathrm{C}_{6}-\mathrm{C}_{27}\right)$ は東京化成工業から入手した。

\section{2 香気エキス抽出方法}

AEDAで生葉の香気寄与成分のFDファクターを求め るため，2014年 4 月28日および熟度が進行した 5 月 14 日に摘採した生葉を用いた。生葉 $0.5 \mathrm{~kg}$ に昇温防止のた めフレーク水 $0.5 \mathrm{~kg}$ と酵素活性を抑えるため $20 \%(\mathrm{w} / \mathrm{v})$ 塩化カルシウム水溶液 0.5 Lを加え, フードプロセッサー （DLC, Cuisinart）で 5 分攪拌した。 5 L容丸底フラス コに移し, 塩化ナトリウムで塩析後, dichloromethane $1 \mathrm{~L}$ 加え 1 時間還流した。常温で 2 時間以上静置後, 水相を除去し, dichloromethaneを回収した。エマルシ ヨンは遠心分離（5000 rpm, $2 \mathrm{~min}$ ) に次いでceliteで ろ過し, dichloromethaneを回収した。これを 3 回繰り 返し, 生葉1.5 kgから香気エキスを抽出した。その後,

Table 1. Characteristic of Raw Material Leaves and Chemical Compositions

\begin{tabular}{|c|c|c|c|c|c|c|c|}
\hline \multirow{3}{*}{$\begin{array}{c}\text { Plucking } \\
\text { date }\end{array}$} & \multicolumn{5}{|c|}{ Characteristic of Raw Material Leaves } & \multicolumn{2}{|c|}{ Chemical Compositions } \\
\hline & $\begin{array}{l}\text { Weight of } \\
100 \text { Shoots }\end{array}$ & $\begin{array}{l}\text { Length of } \\
\text { New Shoot }\end{array}$ & $\begin{array}{l}\text { Rate of } \\
\text { leaves }\end{array}$ & $\begin{array}{c}\text { Bulk } \\
\text { density }\end{array}$ & $\begin{array}{c}\text { Rate of } \\
\text { Banjhi Shoot }\end{array}$ & $\mathrm{NDF}^{\mathrm{a}}$ & Caffeine \\
\hline & $\mathrm{g}$ & $\mathrm{mm}$ & $\%$ & $\mathrm{~kg} \cdot \mathrm{m}^{-3}$ & $\%$ & $\% \mathrm{db}$ & $\% \mathrm{db}$. \\
\hline 28-Apr & 47 & 84 & 74 & 113 & 0 & 12.7 & 3.65 \\
\hline 2-May & 64 & 105 & 71 & 85 & 3 & 15.2 & 3.27 \\
\hline 6-May & 78 & 123 & 78 & 89 & 20 & 18.5 & 3.04 \\
\hline 10-May & 101 & 130 & 71 & 70 & 36 & 20.5 & 2.78 \\
\hline 14-May & 133 & 151 & 74 & 59 & 49 & 23.6 & 2.52 \\
\hline
\end{tabular}


Table 2. Identification of Key Odorants in the Volatile Fractions Isolated from Fresh Tea Leaves

\begin{tabular}{|c|c|c|c|c|c|c|c|c|}
\hline \multirow{4}{*}{ Odorant } & \multirow{4}{*}{ Odor quality } & \multirow{4}{*}{ Fraction $^{\mathrm{a}}$} & \multicolumn{4}{|c|}{ Identification } & \multirow{2}{*}{\multicolumn{2}{|c|}{ Flavor dilution factor }} \\
\hline & & & \multicolumn{2}{|c|}{$\operatorname{SIM}^{\mathrm{b}} \mathrm{m} / \mathrm{z}$} & \multicolumn{2}{|c|}{ Retention index ${ }^{\mathrm{c}}$} & & \\
\hline & & & product & molecular & PureWAX & DB-5MS & Pluckin & date \\
\hline & & & & & PureWAX & DB-5MS & 28-Apr & 14-May \\
\hline 1 3-methylbutanal ${ }^{\mathrm{d}}$ & sweet & $\mathrm{N}-2$ & & & 906 & 651 & 10 & $\overline{10}$ \\
\hline 2 unknown $^{\mathrm{f}}$ & sweet & & & & 1003 & & 10 & 10 \\
\hline 3 1-penten-3-one ${ }^{e}$ & floral & $\mathrm{N}-3$ & & & 1012 & 679 & 100 & 100 \\
\hline 4 unknown $^{\mathrm{f}}$ & sulfy & & & & 1070 & & 10 & 10 \\
\hline 5 hexanal & green & $\mathrm{N}-2$ & & & 1091 & 803 & 10 & 100 \\
\hline 6 dimethyl disulfide ${ }^{\mathrm{e}, \mathrm{g}}$ & sulfy & A & 79 & 94 & 1100 & 785 & 10 & 10 \\
\hline 7 (E)-2-pentenal & fruity & $\mathrm{N}-2$ & & & 1125 & 751 & 100 & 100 \\
\hline $8(Z)-3$-hexenal ${ }^{\mathrm{e}}$ & green & $\mathrm{N}-3$ & & & 1134 & 800 & 1000 & 10000 \\
\hline $9(E)$-2-hexenal & green & $\mathrm{N}-2$ & & & 1192 & 856 & 10 & 10 \\
\hline $10(Z)$-4-heptenal ${ }^{\mathrm{e}}$ & green & $\mathrm{N}-2$ & 68 & 112 & 1225 & 901 & 10 & 10 \\
\hline 11 octanal & fruity & $\mathrm{N}-2$ & & & 1272 & 1006 & 10 & 10 \\
\hline 121 -octen-3-one $\mathrm{e}^{\mathrm{e}}$ & green & $\mathrm{N}-3$ & & & 1291 & 978 & 10 & 10 \\
\hline 13 (E)-2-hexenyl acetate & fruity & $\mathrm{N}-3$ & & & 1309 & 1010 & 100 & 100 \\
\hline 14 unknown $^{\mathrm{f}}$ & fruity & & & & 1339 & & 100 & 10 \\
\hline $15(Z)-1,5$-octadien-3-one ${ }^{\mathrm{e}}$ & metalic-like & $\mathrm{N}-3$ & 55 & 124 & 1363 & 981 & 100 & 1000 \\
\hline $16(Z)$-3-hexenol & green & & & & 1365 & 858 & 100 & 1000 \\
\hline $17(E)$-2-octenal & green & $\mathrm{N}-2$ & & & 1410 & 1060 & & 10 \\
\hline 18 2-isopropyl-3-methoxypyrazine $e^{e}$ & earthy & B & & & 1424 & 1097 & 10 & 100 \\
\hline $19(E, E)$-2,4-heptadienal ${ }^{\mathrm{e}}$ & fatty & $\mathrm{N}-3$ & & & 1495 & 1013 & 100 & 100 \\
\hline 202 -is obutyl-3-methoxypyrazine ${ }^{e}$ & earthy & $\mathrm{B}, \mathrm{N}-5$ & & & 1517 & 1175 & 100 & 100000 \\
\hline $21(E)$-2-nonenal & green & $\mathrm{N}-2$ & & & 1522 & 1158 & 100 & 100 \\
\hline 22 linalool & floral & & & & 1537 & 1101 & 100000 & 100000 \\
\hline $23(E, Z)-2,6$-nonadienal ${ }^{\mathrm{e}}$ & green & $\mathrm{N}-3$ & & & 1572 & 1150 & 10 & 10 \\
\hline 24 unknown $^{\mathrm{f}}$ & green & & & & 1599 & & & 100 \\
\hline 25 phenylacetaldehyde & floral & $\mathrm{N}-3$ & & & 1614 & 1049 & 10 & 10 \\
\hline 26 iso valeric acid & unpleasant & A & & & 1650 & 835 & & 10 \\
\hline 27 3-methylnonane-2,4-dione ${ }^{e}$ & green & $\mathrm{N}-3$ & & & 1706 & 1256 & 100 & 100 \\
\hline $28(E, E)-2,4$-decadienal ${ }^{\mathrm{e}}$ & fruity & $\mathrm{N}-3$ & & & 1794 & 1325 & 100 & 100 \\
\hline $29 \beta$-damascenone $e^{\mathrm{e}, \mathrm{g}}$ & sweet & $\mathrm{N}-3$ & 177 & 192 & 1802 & 1387 & 100 & 100 \\
\hline 30 3-mercapto-1-hexanol ${ }^{\mathrm{e}}$ & fruity & A & & & 1821 & 1125 & 100 & 100 \\
\hline 31 geraniol & floral & & & & 1829 & 1250 & 10000 & 10000 \\
\hline 32 unknown $^{\mathrm{f}}$ & sweet & $\mathrm{N}-3$ & & & 1975 & & 100 & 10 \\
\hline 33 unknown $^{\mathrm{f}}$ & floral & & & & 2026 & & 100 & 100 \\
\hline 34 sotolon ${ }^{\mathrm{e}, \mathrm{g}}$ & spicy & A & & 128 & 2163 & 1112 & 10 & 10 \\
\hline $35(Z)$-methyljasmonate & floral & $\mathrm{N}-4$ & & & 2370 & 1675 & 10 & 10 \\
\hline 36 coumarin & sweet & $\mathrm{N}-3$ & & & 2420 & 1438 & 100 & 10 \\
\hline 37 vanillin & sweet & $\mathrm{N}-3$ & & & 2533 & 1419 & 100 & 10 \\
\hline
\end{tabular}

${ }^{a}$ Acidic, basic and neutral fractions were isolated from aroma extract. The neutral fraction was applied to a column $(60 \times 16 \mathrm{~mm}$ i.d., $12 \mathrm{~mL})$ containing silica gel (5 g, particle size $40 \mathrm{~mm}$, Agilent). Samples were eluted in one of the following solvents: pentane (36 mL, fraction N-1), pentane/dichloromethane ( $24 \mathrm{~mL} / 12 \mathrm{~mL}$, fraction N-2), pentane/dichloromethane (12 mL/24 mL, fraction N-3), dichloromethane (36 mL, fraction N-4), and ethyl acetate $\left(50 \mathrm{~mL}\right.$, fraction N-5). ${ }^{b}$ Selected ion mode (SIM). ${ }^{c}$ Retention index was caluculated by using GC-FID. ${ }^{\mathrm{d}}$ The odorant has been identified by using the solid phase microextraction. ${ }^{\mathrm{e}}$ Since mass spectra of an odorant could not be obtained, SIM was applied to the detection of the odorant. 'Unidentifed odorant. ${ }^{\mathrm{g}}$ The odorant was not detected when the fraction was injected on the PureWAX capillary column. However, the peak was observed when the separated fraction was injected onto the DB-5MS capillary column.

dichloromethaneをシュナイダー管で20 $\mathrm{mL}$ で濃縮し (温度 $45^{\circ} \mathrm{C}$ ), 既報 ${ }^{14)}$ に従いSAFE装置で高真空蒸留した。 蒸留液はシュナイダー管に次いで, 窒素気流で $0.1 \mathrm{~mL}$ で濃縮し，AEDAに用いた。

生葉の熟度の進行による香気寄与成分の変化を調べ るため，4月28日，5月 2 日，5月 6 日，5月10日お よび 5 月14日に摘採した生葉を用いた。生葉 $0.1 \mathrm{~kg}$ に フレーク水 $0.1 \mathrm{~kg}, 20 \%(\mathrm{w} / \mathrm{v})$ 塩化カルシウム水溶
液0.1 L,さらに内標準としてethyl decanoate $590 \mu \mathrm{g}$ を加え：ミキサー（TMD, Tescom）で 1 分擋拌した。 1 L容丸底フラスコに移し，塩化ナトリウムで塩析後， dichloromethane 0.3 Lで還流した。常温で 2 時間以上 静置後水相を除去し, dichloromethaneを回収した。エ マルションは遠心分離（5000 rpm, $2 \mathrm{~min}$ ) に次いでcelite でろ過し, dichloromethaneを回収した。シュナイダー管 で20 mLまで濃縮後, SAFE装置で高真空蒸留した ${ }^{14)}$ 。 
蒸留液をシュナイダー管に次いで窒素気流で $0.2 \mathrm{~mL}$ ま゙ 濃縮し，GC-マススペクトロメトリー（MS）分析に用 いた。

\section{3 成分分析}

摘採した生葉0.5 kgを送帯式蒸機（SD-500，寺田製作 所）で40秒蒸熱後, 熱風式乾燥機で乾燥した。これを茶 成分分析計専用のサイクロンサンプルミル (Udy) で粉 砕し, 茶成分分析計 (GT-8, 静岡製機) で中性デター ジェント繊維（NDF）を分析した。既報15.16) に従い，高 速液体クロマトグラフィー (HPLC) でアミノ酸含有量 ${ }^{15)}$, カフェインおよびカテキン類の含有量 ${ }^{16)}$ を分析した。 $\mathrm{GC}-\mathrm{O} /$ 水素炎イオン化検出器 (FID) 分析およびGC-マ ススペクトロメトリー（MS）分析は既報14.17) に従った。

生葉の熟度の進行による香気寄与成分の変化を明ら かにするため, GC-MSのSelected ion mode (SIM) で 分析した。GC-MS分析条件は既報 ${ }^{14,17)} に$ に従い, Table 3 に示したイオンを検出した。な扮分離カラムはDB-5MS $(30 \mathrm{~m} \times 0.25 \mathrm{~mm}$ i.d; film thickness, $0.25 \mu \mathrm{m}$, Agilent) を用いた。

\section{4 AEDA}

既報 ${ }^{18)}$ と同様に，香気エキス $0.1 \mathrm{~mL}$ をdichloromethane で10倍，100倍，1000倍，10000倍に希釈し，GC-O分析 した。な扔, 分析は 3 回繰返し, その内 2 回以上匂いが 検出される最大の希釈倍率をFDファクターとした。

\section{5 香気寄与成分の特定}

香気寄与成分を特定するため, AEDAに用いた全て の香気エキスおよび分析に用いた香気エキスを混合し， 既報 ${ }^{9}$ に従い分画した。各画分に含まれる成分を分離
カラムPureWAXとDB-5MSを用いてGC-O/FIDおよび GC-MS分析し, 匂いの性質, マススペクトル, 保持指標 から成分を特定した。なお，マススペクトルが得られな い場合，匂いの性質および保持指標とともに， Table 2 に示した各成分のプロダクトイオンと分子イオンをSIM で検出することで特定した。

\section{3 実験結果及び考察}

\section{1 熟度の進行による生葉の形質と成分変化}

実験に用いた生葉の形質を把握するため, 生葉の百芽 重, 芽長, かさ密度, 出開き度, 葉割合を求めた。さら に茶成分分析計でNDFを，HPLCでカフェイン，アミノ 酸，カテキンを分析した。用いた生葉の百芽重，芽長， 出開き度は熟度の進行により増加した。その一方, かさ 密度は減少したが, 葉割合に大きな変化は認められなか った（Table 1)。NDFは熟度の進行にともない増加し， カフェインは減少した（Table 1)。いずれのアミノ酸も 生葉の熟度の進行にともない減少したが, 特にアルギニ ンの減少は顕著であった（Table 4)。カテキンの含有量 は熟度の進行にともない僅かに減少しているが, 個別 に見ると, gallocatechinと epigallocatecinは増加するが, catechin, epigallocatechin gallate, epicatechin gallate の 3 つのカテキンは減少した（Table 5)。これら成分の 熟度の進行による変化は既報と一致した ${ }^{19}$ 。

\section{2 香気寄与成分の特定}

Table 2にGC-O分析で検出された香気寄与成分，匂い の性質, 成分の特定に至った画分, 保持指標およびFD ファクターを示した。GC-O分析により37成分が検出さ れ，その内31成分を特定した。No.16 (Z)-3-hexenol,

Table 3. Selected Ion Mode (SIM) for Mass Chromatography

\begin{tabular}{|c|c|c|c|c|c|}
\hline \multirow{3}{*}{ No. } & \multirow{3}{*}{ Odorant } & \multirow{2}{*}{\multicolumn{2}{|c|}{$\frac{\text { Flavor dilution factor }}{\text { Plucking date }}$}} & \multicolumn{2}{|c|}{$\mathrm{SIM}^{\mathrm{a}} \mathrm{m} / \mathrm{z}$} \\
\hline & & & & \multirow{2}{*}{ monitor ion } & \multirow{2}{*}{$\begin{array}{c}\text { ion for } \\
\text { quantification }\end{array}$} \\
\hline & & 28-Apr & 14-May & & \\
\hline \multicolumn{2}{|c|}{5 hexanal } & 10 & 100 & 56,72 & 72 \\
\hline \multicolumn{2}{|c|}{8 (Z)-3-hexenal } & 1000 & 10000 & $69,83,98$ & 98 \\
\hline \multicolumn{2}{|c|}{15 (Z)-1,5-octadien-3-one } & 100 & 1000 & 55,124 & 124 \\
\hline \multicolumn{2}{|c|}{16 (Z)-3-hexanol } & 100 & 1000 & 82,100 & 100 \\
\hline \multicolumn{2}{|c|}{18 2-is opropyl-3-methoxypyrazine } & 10 & 100 & 137,152 & 152 \\
\hline \multicolumn{2}{|c|}{20 2-isobutyl-3-methoxypyrazine } & 100 & 100000 & 124,151 & 151 \\
\hline \multicolumn{2}{|c|}{36 coumarin } & 100 & 10 & 118,146 & 146 \\
\hline \multicolumn{2}{|c|}{37 vanillin } & 100 & 10 & 151,152 & 152 \\
\hline
\end{tabular}

${ }^{\text {a }}$ Selected ion for the semi-quantification of the odorant by using an internal standard of ethyl decanoate ( $\mathrm{m} / \mathrm{z} 200)$. The odorant listed in the table was semi-quantified by using a DB-5MS column. 
Table 4. Concentrations of Amino Acids in Raw Material Leaves

\begin{tabular}{ccccccccccc}
\hline \multirow{2}{*}{$\begin{array}{c}\text { Plucking } \\
\text { date }\end{array}$} & \multicolumn{8}{c}{ Amino acids } & \multirow{2}{*}{ Total } \\
\cline { 2 - 9 } & Asp & Glu & Asn & Ser & Gln & Arg & Ala & Thea & \\
\hline 28-Apr & 0.36 & 0.44 & 0.01 & 0.13 & 0.53 & 1.05 & 0.03 & 2.35 & 4.89 \\
2-May & 0.33 & 0.38 & 0.02 & 0.09 & 0.71 & 0.81 & 0.03 & 2.27 & 4.65 \\
6-May & 0.24 & 0.30 & 0.01 & 0.10 & 0.65 & 0.43 & 0.03 & 1.91 & 3.68 \\
10-May & 0.24 & 0.36 & 0.01 & 0.07 & 0.48 & 0.29 & 0.03 & 1.76 & 3.24 \\
14-May & 0.21 & 0.28 & 0.00 & 0.05 & 0.31 & 0.15 & 0.02 & 1.33 & 2.36 \\
\hline \multicolumn{8}{l}{ Asp; aspartic acid, Glu; glutamic acid, Asn; asparagine, Ser; serine, Gln; glutamine, } \\
& Arg; arginine, Ala; alanine, Thea; theanine. Total includes Asp, Glu, Asn, Ser, Gln, \\
& Arg, Ala and Thea. (\% db.)
\end{tabular}

Table 5. Concentrations of Catechins in Raw Material Leaves

\begin{tabular}{|c|c|c|c|c|c|c|c|}
\hline \multirow{2}{*}{$\begin{array}{c}\text { Plucking } \\
\text { date }\end{array}$} & \multicolumn{6}{|c|}{ Catechins } & \multirow{2}{*}{ Total } \\
\hline & GC & EGC & $\mathrm{C}$ & EGCG & $\mathrm{EC}$ & ECG & \\
\hline 28-Apr & 0.12 & 3.91 & 0.31 & 7.84 & 1.42 & 1.27 & 14.9 \\
\hline 2-May & 0.11 & 3.85 & 0.22 & 6.61 & 1.42 & 1.04 & 13.3 \\
\hline 6-May & 0.16 & 4.50 & 0.12 & 6.31 & 1.43 & 0.86 & 13.4 \\
\hline 10-May & 0.16 & 4.74 & 0.10 & 6.17 & 1.32 & 0.78 & 13.3 \\
\hline 14-May & 0.16 & 4.95 & 0.06 & 5.83 & 1.34 & 0.73 & 13.1 \\
\hline
\end{tabular}

No.22 linalool, No.31 geraniolの 3 成分はGC-O分析に おいてFIDのピーク（Fig. 1）と人の鼻が検出する保 持時間が一致し, GC-MS分析において分画しなくて もマススペクトルを取得できた。その他の香気寄与成 分は香気エキスを分画し，各画分をGC-OとGC-MS 分析することで特定することができた。ただし，No.6 dimethyl disulfide, No. $10(Z)$-4-heptenal, No. $15(Z)$ -1,5-octadien-3-one, No. $29 \beta$-damascenone, No. 34 sotolonの 5 成分は分画してもマススペクトルは得られ なかったため, SIMで検出することで確認した。No.6, 29, 34の 3 成分は分離カラムPureWAXを用いたGC-MS 分析で検出されなかったが, 分離カラムDB-5MSを用い ることで検出できた。
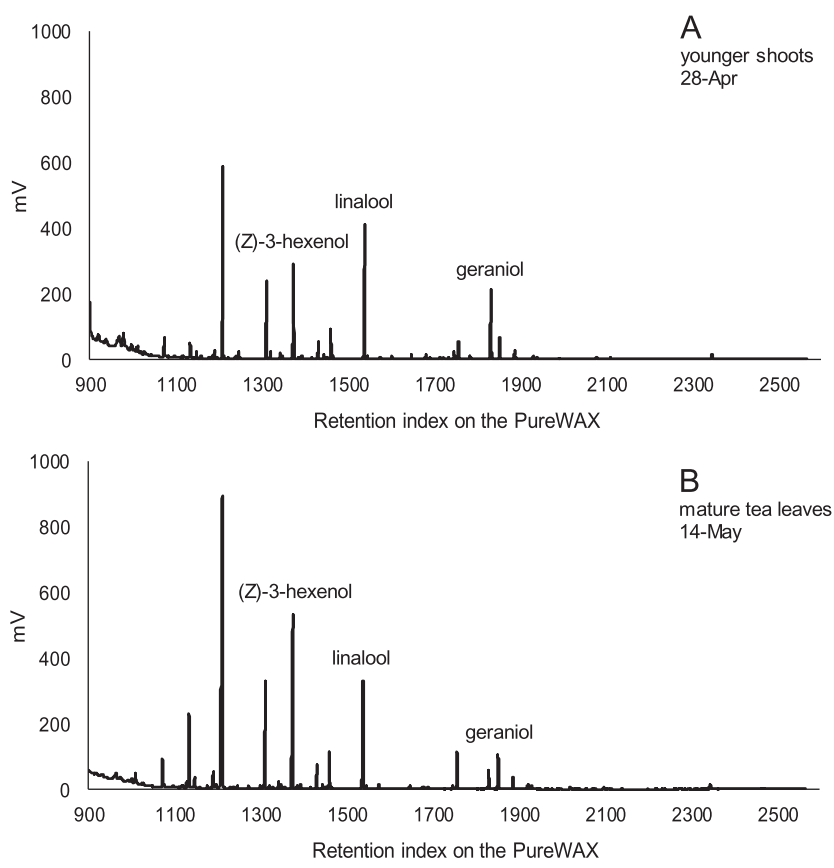

Fig. 1. GC-flame ionization detector chromatogram of the volatile concentrate of the younger shoots plucked on 28-Apr (A) and mature tea leaves plucked on 14-May (B) with showing the three peaks of odorant [(Z)-3-hexenol; linalool; geraniol]. 


\section{3 生葉に含まれる香気寄与成分}

Dichloromethaneで抽出した生葉の香気エキスは生葉 の香りを忠実に再現していた。4月28日に摘採した生 葉から最も高いFDファクター100000でNo.22 linaloolが 検出された（Table 2)。次いで高いFDファクター10000 でNo.31 geraniolが, FDファクター1000でNo.8 (Z) -3-hexenalが検出された。一方, 熟度が進行した 5 月 14 日に摘採した生葉から最も高いFDファクター100000で No.20 2-isobutyl-3-methoxypyrazineとNo.22 linaloolが 検出された。次いで高いFDファクター10000でNo.8（Z) -3-hexenalとNo.31 geraniolが, FDファクター1000で No.15 (Z)-1,5-octadien-3-one, No.16 ( $Z$ )-3-hexenolが 検出された。

\section{4 熟度の進行による香気寄与成分の変化}

高いFDファクター100以上で検出された成分 に扮いて, 熟度が進行した生葉の方が高いFDフ アクターで検出された成分を見ると（Table 2),
No.5 hexanal, No.8 (Z)-3-hexenal, No.15 ( $Z$ ) -1,5-octadien-3-one, No.16 ( $Z$ )-3-hexenol, No.18 2-isopropyl-3-methoxypyrazine, No.20 2-isobutyl3-methoxypyrazine, No.24 unknownの 7 成分であっ た。一方で, FDファクター100以上で検出された成分 に扔いて, 熟度が進行した生葉の方が低いFDファク ターを示した成分はNo.32 unknown, No.36 coumarin, No.37 vanillinであった。これら香気寄与成分の熟度の 進行による変化を調べるため, GC-MSのSIMを用いた (Table 3)。熟度の進行により高いFDファクターで検 出されたNo. 5 hexanal, No.8 (Z)-3-hexenal, No.15 (Z)-1,5-octadien-3-one, No.16 (Z)-3-hexenol, No.18 2-isopropyl-3-methoxypyrazine, No.20 2-isobutyl3-methoxypyrazineの 6 成分は熟度の進行で増加した (Fig. 2)。これらの成分の増加によって茶の香りが変化 し，こわ葉臭等の香りに関与することが考えられる。一 方, 熟度の進行により低いFDファクターで検出された No.36 coumarin, No.37 vanillinは熟度の進行により減少
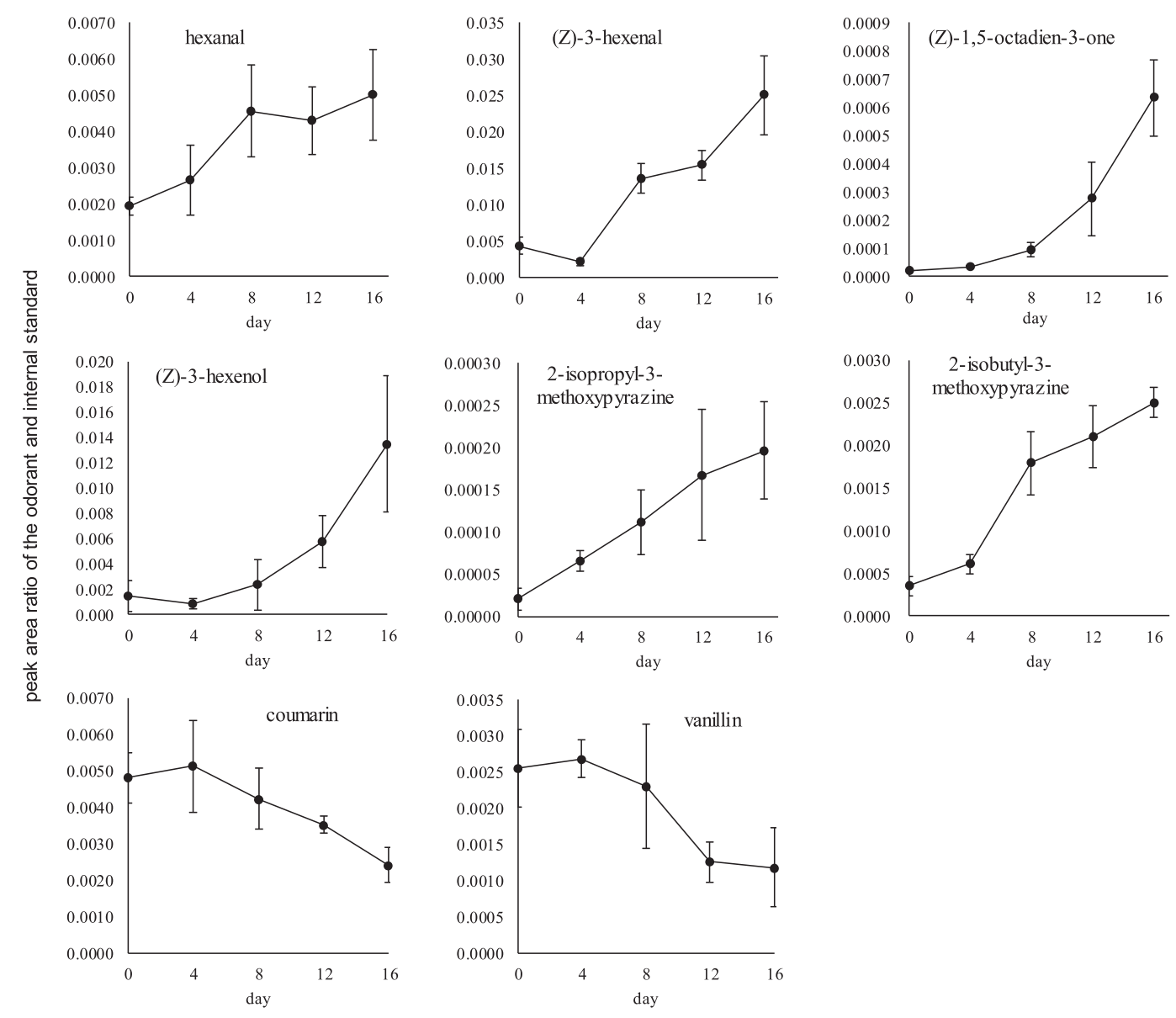

Fig. 2. Peak area ratio of the odorant and internal standard in aroma extract isolated from fresh tea leaves with maturity. The error bars in the Fig show standard deviations calculated from three iterative analyzes. 
した (Fig. 2)。coumarinは桜葉のような甘い香りがあり， vanillinはバニラの甘い香りがある。従って, これらの 香気寄与成分は若芽が持つ特有の甘い香りに貢献するこ とが考えられる。

熟度の進行により増加したhexanal ${ }^{20)},(Z)-3$-hexenal ${ }^{20)}$, (Z)-1,5-octadien-3-one ${ }^{21),}(Z)$-3-hexenol ${ }^{20)}$ はlinolenic acidから酸化や分解を経て生成することが知られてい る。また $(Z)$-3-hexenolはアグリコンとして存在するこ とも知られている ${ }^{20)}$ 。No.18とNo20のmethoxypyrazine は生野菜，ナッッ，大豆，ワイン，グレープ等に含ま れ, No.18はvalineから, No.20はleucineから生育中の代

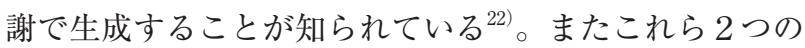
methoxypyrazineは夏茶臭の主要因成分である ${ }^{9)}$ 。一方, 熟度の進行により減少したcoumarinは小柳津ら ${ }^{1)} も$ 同 様に熟度の進行による減少を認めているが, vanillinと 同様に消長機構は明らかにされていない。

熟度の進行による成分の消長機構は他の研究によらな ければならないが，本研究で得られたデー夕は，こわ葉 臭等の解明や, 今後の栽培拉よび加工技術の発展に貢献 することが期待される。

\section{4 摘 要}

本研究は熟度の進行による香りの変化を明らかにする ことを目的として行った。生葉に含まれる香気成分は 製茶工程を経ると著しく変化することが予想されたた め, 生葉から直接香りを抽出し, 分析に用いた。生葉か ら抽出した香気エキスを解析したところ, hexanal， $(Z)$ -3-hexenal, (Z)-1,5-octadien-3-one, $(Z)$-3-hexenol, 2-isopropyl-3-methoxypyrazine, 2-isobutyl-3methoxypyrazineの6成分は熟度の進行により増加し, 高いFDファクターで検出された。従って，これらの成 分はこわ葉臭等の香りに関与することが考えられた。一 方, 熟度の進行により coumarinとvanillinは減少し, こ れらは甘い香りがあることから, 若芽の持つ甘い香りに 関与していることが考えられた。

\section{5 引用文献}

1 ) 小柳津 勉・下田満哉・松本 浩・後藤 正 (2002): 茶芽の熟 度による緑茶香気成分の変化.食科工誌, 49,327-334.
2 ）高柳博次 ·阿南豊正 - 池ヶ谷堅次郎・中川致之 (1985) : 茶芽の 熟度と成分変動.茶研報, No.61,20-25.

3 ) 吉田優子 - 木曽雅昭 ·長嶋 等・後藤哲久 (1996): 茶芽の生育 に伴う化学成分含量の変化. 茶研報, No.83,9-16

4 ）深津修一・岩浅 潔 (1978): 煎茶製造工程に掞ける香気成分の 変化.茶研報, No.48,68-76.

5 ) 水上裕造 (2015): 緑茶の香りの特徵.におい・かおり環境学会 誌, 46,110-120.

6 ) Kumazawa, K (2006): Flavor chemistry of tea and coffee drinks. Food. Sci. Technol. Res., 12, 71-84.

7 ) 水上裕造 (2017): Solvent-assisted flavor evaporation装置を用 いた高真空蒸留と香気エキス希釈分析法による台湾産半発酵 茶の香気寄与成分の特定.茶研報, No.123,9-16.

8 ) 水上裕造・山口優一 (2010):2006年から2010年に扔ける一番茶 の原葉形質と荒茶品質.茶研報,No.110,91-94.

9 ) 水上裕造 - 崎原敏博 - 遠矢聡志 - 内村浩二 (2014) : 夏茶に含ま れる香気寄与成分. 茶研報, No.117,27-33.

10）水上裕造 (2013) : 煎茶のヘッドスペースと浸出液に含まれる香 気寄与成分. 茶研報, No.116,15-21.

11) Mukaiyama, T., J. Matsuo and M. Yanagisawa (2001): A mild and efficient oxidation of alcohols with $\mathrm{N}$-tertButylphenylsulfinimidoyl chloride in the coexistence of zinc oxide. Chem. Lett., 30, 150-151.

12) Swoboda, P. A. T. and K. E. Peers (1977): Metallic odour caused by vinyl ketones formed in the oxidation of butterfat. The identification of octa-1-cis-5-dien-3-one. J. Sci. Food Agric., 28, 1019-1024.

13) Yuasa, Y. and Y. Kato (2001):Practical synthesis of 3-methylnonane-2,4-dione, an intense strawlike and fruity flavored compound. J. Agric. Food Chem., 49, 3864-3866.

14）水上裕造·山口優一(2010): Solvent-assisted flavor evaporation 装置を用いた茶に含まれる香気成分の分析法. 茶研報,No.110, 105-112.

15）水上裕造 ・邑田修三・濱田倫哉 (2012)：メチルメチオニンスル ホニウムを含むアミノ酸分析. 茶研報,No.114(別),122-123.

16）水上裕造 (2013) : 浸出条件がほうじ茶の香気寄与成分とカテキ ン含量に及ぼす影響.茶研報,No.116(別),126-127.

17) 水上裕造 (2012) : Solvent-assisted flavor evaporation装置を用 いた高真空蒸留と香気エキス希釈分析法によるほうじ茶葉香 気寄与成分の特定. 茶研報, No.113,55-62.

18）水上裕造 - 崎原敏博 - 飛松 諒 · 内村浩二 (2015) : 生葉の低温 保管による夏茶臭改善効果の解明.茶研報,No.119,21-28.

19）伊奈和夫・鈴木壯幸 (2007)：吕チャ葉 (生葉)の化学成分.伊奈和 夫・坂田完三編「新版 緑茶・中国茶・紅茶の化学と機能」,株 式会社アイ・ケイコーポレーション,pp.26-54.

20) Chi-Tang, H., Z. Xin and L. Shiming (2015): Tea aroma formation. Food Sci. Human Wellness, 4, 9-27.

21) Ullrich, F. and W. Grosch (1988): Identification of the most intense odor compounds formed during autoxidation of methyl linolenate at room temperature. J. Am. Oil Chem., 65, 1313-1317.

22) Murray, K. E. and F. B. Whitfield (1975): The occurrence of 3-alkyl-2-methoxypyrazine in raw vegetable. J. Sci. Food. Agric., 26, 973-986. 